\title{
Leadership in Print
}

Can Ethies Be Taught?

Perspectives, Challenges, and Approaches at Harvard Business School

Thomas R. Piper, Mary C. Gentile, and

Sharon Daloz Parks

Foreword by John H. McArthur

Can Ethics Be Taught? traces the evolution, strategy, and implementation of the pathbreaking Leadership, Ethics, and Corporate Responsibility program at the Harvard Business School. The lessons drawn from the experience of those who

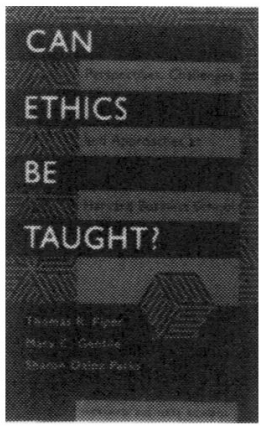
initiated the program will prove instructive to other professional schools and to corporate leaders, as they design and implement their own programs on leadership, ethics, and responsibility.

$\$ 19.95$

208 pages

\section{Good Intentions Aside} A Manager's Guide to Resolving Ethical Problems Laura L. Nash, Boston University

"Nash drives home the need for sound business ethics in the 1990s and beyond. Through a multitude of real-world dilemmas, she convincingly dissolves the assumption that ethics has no place in business and that ethical considerations will only impede the maximization of profit . . . Much applause for this timely guide that bridges the gap between the moral and economic sense of 'good' business."

-Insights on Global Ethics

$\$ 14.95$ paperback $\quad 288$ pages

\section{Leadership and the Quest for Integrity}

Joseph L. Badaracco, Jr., Harvard Business School and Richard R. Ellsworth, The Claremont Graduate School

"In its unique synthesis of practical experience and sound conceptual analysis, this book will provide stimulus, insight, and vision even to the accomplished and successful executive."

-Peter F. Drucker

$\$ 14.95$ paperback 224 pages

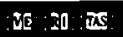

Harvard Business School Press

BOSTON, MA $02163 \cdot 1-800-545-7685$ ext. 062A 


\title{
GUIDELINES FOR CONTRIBUTORS
}

\author{
General Information
}

Manuscripts are considered for publication on the understanding that they are not concurrently under consideration elsewhere and that the material-in substance as well as form-has not been previously published.

Three copies of the manuscript should be submitted.

Authors should identify themselves only on a separate title page that provides name, mailing address, and telephone number. Authors must also remember not to identify themselves in the body of the manuscript; specitically, references to their own work in the text should be in the third person, and citations should be written without possessive pronouns-not "See my. . .."

Each article should be accompanied by a précis of 75-100 words outlining the main point(s) of the paper and placing the article in context. Subheads should be used to divide the manuscript into three or four sections (or more, depending on length).

We do not have an upper or lower page limit, but articles usually run between 25 and 60 typescript pages, including notes and other material.

Articles must contain notes in the humanities style, not references as in the social sciences. We are always eager to publish illustrations, but authors should not include originals of illustrative materials at the time of subnission; photocopies of such material may be included.

Authors of accepted manuscripts will receive two copies of the issue in which the article appears and twenty-five free offprints.

\section{Manuscript Prpamtion}

ALL material-including extracted quotations and notes-must be double-spaced. Legible photocopies or word-processed originals may be submitted. Use of dot-matrix printers is discouraged.

Notes should be numbered consecurively and citations should be placed at the end of the text. Do not place footnotes at the bottom of the page (see word-processing instructions).

Each table or figure should ocupy a separate page and should be numbered (in arabic numerals) and grouped together between the text and the notes. The position of these items should be indicated in the text (as, "see Table 3"), but they should not be mingled with the text and no extra space should be lett for them there. Each table and figure must be accompanied by a complete source.

We use the 13th edition of The Chicago Manual of Style (1982) and spell and hyphenate words according to Webster's Ninth New Collegiate Dictionary.

The journal encourages authors to use gender-neutral prose in all cases where it is not anachronistic to do so; male nouns and pronouns should not be used to refer to people of both sexes.

We use the day-month-year form for dates, as 11 Februan 1990.

Double quotation marks should be used for journal titles and direct quotation; single quotation marks are used for quoted material inside quotations.

\section{Sample Citation Forms:}

Book: Alfred D. Chandler, Jr., The Visible Hand: The Managerial Revolution in American Business (Canbridge, Mass. , 1977), 321-22.

Journal: Charles Cheape, "Not Politicians but Sound Businessmen: Norton Company and the Third Reich," Business History Review 62 (Autumn 1988): 444-66.

Note that we do not include the publisher in book citations. We do not use loc. cit. , op. cit., or idem., but ibid. (not italicized) may be used.

\section{Wond-Processing Guidelines}

The journal can accept disks of all standard sizes and densities, but they must be formatted in MS-DOS; we cannot use Apple or Macintosh software. WordPerfect is directly compatible, but we may be able to accept your document if it can be converted into an ASCII file.

Potential contributors should submit hard copy, not diskettes, initially, but it will save considerable work for all parties in the event of acceptance if authors working on PCs follow a few rules from the beginning:

In general, use as few formatting commands as possible.

Do not justify or halt-justify the right-hand margin.

Do not hyphenate words at the end of lines.

Do not use hard returns except for new paragraphs or required page ends except as absolutely necessary (for example, to break between text and notes).

Do not use special fonts; underline material that is to be set in italics.

Most important, do not use the word processor's automatic footnote functions: do not embed notes in the text. Notes should be keyed in at the end of the text (after any tables) or as a separate file. 


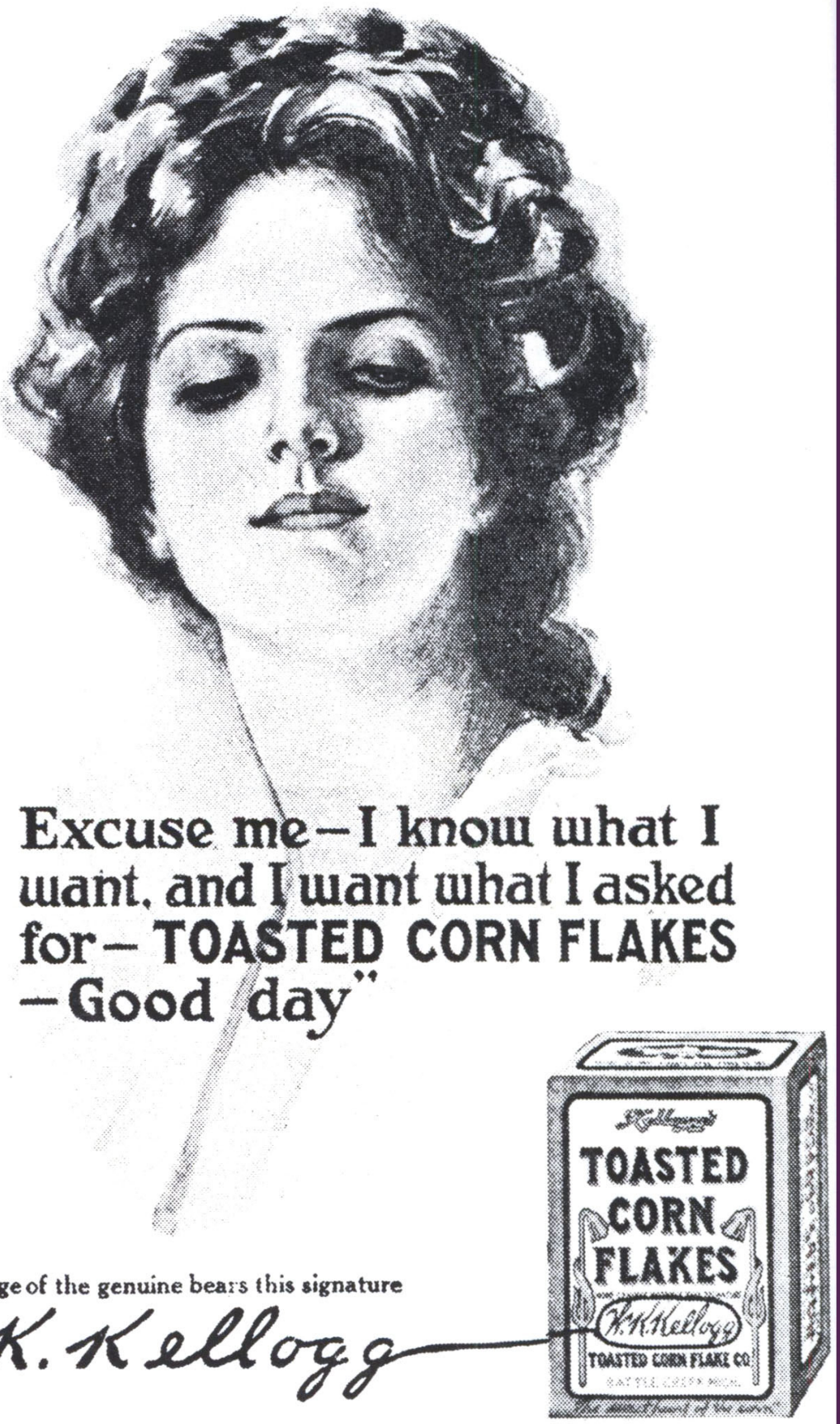

The package of the genuine bears this signature W. K. Kellogg 